\title{
A Validity Study of Attitudes toward Science Scale among Iranian Secondary School Students
}

\author{
Muhammad J. Liaghatdar \\ School of Education, University of Isfahan \\ PO box 81746 73441, Isfahan, Azadi square, University of Isfahan, Iran \\ Tel: 98-311-793-2536Ｅ-mail: javad@edu.ui.ac.ir \\ Asghar Soltani (Corresponding Author) \\ Faculty of Literature and Humanities, School of Education \\ Shahid Bahonar University of Kerman, Iran \\ PO box 76169133, Shahid Bahonar University of Kerman, Afzalipour square, Kerman, Iran \\ Tel: 98-913-209-3549Ｅ-mail: asghar.soltani.k@gmail.com
}

Ahmad Abedi
School of Education, University of Isfahan

PO box 81746 73441, Isfahan, Azadi square, University of Isfahan, Iran

Tel: 98-311-793-2548Ｅ-mail: a.abedi@edu.ac.ir

Received: June 23, 2011 Accepted: July 1, $2011 \quad$ Published: November 1, 2011

doi:10.5539/ies.v4n4p36

URL: http://dx.doi.org/10.5539/ies.v4n4p36

\begin{abstract}
The purpose of this study is providing a scale for measuring attitudes toward science among Persian secondary school students. A total of 300 (150 girls and 150 boys) of second grade students from all disciplines including science and mathematics in secondary education, participated in the study. Research instrument was, translated Persian version of Simpson - Troost Attitude Questionnaire (STAQ). After performing the scale among the sample, the data was analyzed by SPSS software. The reliability of questionnaire was found to be .84 . Factor analysis indicated that more than $35.8 \%$ of the total variance was explained with the scale scores. After factor rotation, five factors of attractiveness of science, the class / teacher, self-directed efforts, anxiety toward science and the family pattern were identified. Thus it was shown that the scale is multidimensional and the dimensions have appropriate reliability and validity to measure attitudes toward science, so this instrument could be used in the next Persian research in measuring attitudes toward science. Multivariate Analysis (MANOVA) of data showed that there is no significant difference between sex and students' attitudes toward science. But in the third factor (self-directed efforts) was a significant difference between sex and students' attitudes toward science and the average of female students were higher than male students. Test results also showed that there is significant different between discipline of students and their attitudes to science and attitudes of empirical science students have the better attitudes than themselves, while science students in first factors (attractiveness of science) and in second factor (class / Teacher), had mean higher average than mathematical physics students.
\end{abstract}

Keywords: Attitude towards science, Scale, Validity study, Secondary school, Science education

\section{Introduction}

Scientific and technological progress in many countries is associated with rapid growth. Part of this development is due to essential consideration to the field of science education. Today the first priority in science education is to improve math and science education from kindergarten to before university. With global growth of science and technology in the form is happening fast, low interest students in science courses and work, is a global concern that demands the reforms in science education in international scale. Because student attitudes toward science affects their future scholar and job choices, so measuring the effect of this reform on the attitudes of students is important 
and requires tools with strong psychometric properties (Owen et al, 2008).

Research have showed that people interests in science, is important to learning science. In fact, the attitude of students is one of the key factors in learning science. Growing positive attitude towards science could improve students' interests in science and related professions to science. Positive attitude can also increases learning of scientific issues formally and informally, after teaching teachers (George, 2006). From other hand, Attitudes toward science is important because attitudes can enhance the educational achievements of students and affect their performance. The students, whom have more positive attitudes, have willingness to better performance in science (Beaton et al, 1996).

One of the issues of attitudinal studies in science education is to assess the elementary, intermediate and secondary students' attitudes toward science (Turkmen, 2007). Assessment of public understanding of science is important not only in science education community, but also from the viewpoints of social scientists (Bak, 2007). This issue is due to the close relations between science, technology and society.

Accordingly, the present research addressing the concept of attitude toward science and its related components, and also introducing the attitude assessment tests in science, examine the validity of Persian scale of attitudes toward science among Iranian secondary school students in science and mathematics courses examine.

\section{Attitudes toward Science and Its Related Components}

Although the definition or concept of attitude in relation to science is vague and inconsistent, however attitude is defined as person's directions in response to emotional affairs, peoples, places, events or ideas (Sipmson and Oliver, 1990). So phrases like "I love science" or "I enjoy science", are considered as attitudes.

Adolescence is one of the most critical periods of human development. Achievement in science as well as attitudes toward science, therefore are of special concern to science educators during this time (Talton and Simpson, 1985). Children shape early their attitudes toward science. Many children who inter to the period of adolescence have the lowest exposures to science after third grade; half of the students feel that they do not like to choose science. Only $21 \%$ of the eight grades have a positive attitude to science (Hurd, 1982). Seven grades students show the first formal orientation towards science. The preliminary experience and orientation toward science affects attitude and commitment of students to science and their future potential science based activities (Simpson and Troost, 1982).

There are many factors that influence attitudes and achievement among adolescents. Some of the factors are associated with parental background and family environment. Other factors relate to individual characteristics such as self-concept, locus of control, and achievement motivation. Still other variables are associated with school influences such as class climate, teachers, and administrative styles (Talton and Simpson, 1985). According to Osborne et al. (2003) studies have incorporated a range of components in their measures of attitudes to science including: the perception of the science teacher; anxiety toward science; the value of science; self-esteem at science; motivation towards science; enjoyment of science; attitudes of peers and friends towards science; attitudes of parents towards science; the nature of the classroom environment; achievement in science; and fear of failure on course. Generally, these factors can be summarized in five cases are:

2.1 Gender: Among the factors the most significant is gender for, as Gardner comments, 'sex is probably the most significant variable related towards pupils' attitude to science'. Research has shown that boys compared with girls consistently have more positive attitudes to school science although this effect in physics is stronger than biology. Prominent theory to describe why this is the consequence of socio-cultural issues that commonly gives fewer opportunities for handling and use of technological tools to the girls.

2.2 Socio - economical Class: Several studies have examined the relationship between socio-economic class and attitudes towards science. Although the results of these researches in some cases are contradictory, although Breakwell and Beardsell's (1992) study did find that class was negatively associated with attitude towards school science - children from lower social class having more positive attitudes showed that lower social class as a negative attitude toward science affects. However, the role of social class in this regard remains uncertain.

2.3 Classroom / teacher: Some research focused on the effects considered classroom environment as an important factor affecting attitudes. Research of Myers and Fouts (1992) showed that that the most positive attitudes were associated with a high level of involvement, very high level of personal support, strong positive relationships with classmates, and the use of a variety of teaching strategies and unusual learning activities. Longitudinal study of Simpson and Oliver (1990) also showed that there were common aspects of teaching that were perceived to be effective by both teachers and pupils. These were:

- clear goals for pupil learning; 
- clarity of communication of lesson goals and agenda to pupils;

- use of preview and review of lesson content;

- helping students to contextualize content in terms of their own experience and knowledge, as well as in terms of other teaching goals and learning experiences;

- some willingness to allow pupils to have input into goal and agenda setting;

- a supportive social context designed by the teacher to help pupils feel accepted, cared for and valued;

- an ability and willingness to allow for different cognitive styles and ways of engaging with the learning process among pupils, through multiple exemplification, and the use of different types of illustration and mode of presentation, and offering pupils a choice from a menu of possible ways of engaging; and

- A willingness to take into account pupil circumstances and to modify/pace/ structure learning tasks accordingly.

Teachers also play an important role in attitude formation. In fact quality of education directly is related to quality of science education and nature of science teaching affects strongly students' attitudes toward science. The fact that classroom environment is under direct control of the educator is significant. By increasing teacher awareness to the important role that classroom environment may play in the formation of student attitudes toward science it may be possible to substantially increase student interest and achievement in science. If classrooms are fashioned into stimulating, supportive environments in which students may question and develop their interests in science, an important educational goal may be achieved. Self-concept in science should also improve if students are given a supportive environment in which they can explore the nature of science (Talton and Simpson, 1986).

2.4 Peers: one of the factors that greatly have been studied in science education is the effect of peers and friends. How friends in general and best friends in particular view and perform in science may be an important influence (Talton and Simpson, 1985) However, some related variables such as personal motivation, home, school and peers are in partial control teachers (Kremer and Walberg, 1981). Children and adolescents consider peoples a model that that they respect and encourage them and feel close relations with. Typically whose are as models that have the most relations, such as parents, siblings, peers and may be elder friends (Owen, Froman and Moscow, 1981). Norms shown by such peers will help to guidance students' behavior and attitudes (Fishbein and Ajzen, 1975).

2.5 Family: Family and home environment also have strong impact on adolescent attitudes. The more parents' involvement in academic affairs of students will lead to higher level of scientific attitudes and interest in them. Interest rates of each the parents, siblings and their cooperation with students are effective on attitude toward science (Osborne et al., 2003).

\section{Attitudes toward Science Scales}

The investigation of students' attitudes towards studying science has been a substantive feature of the work of the science education research community for the past 30-40 years (Osborne et al., 2003). Since Null challenged instructors for thinking about measurement of scientific attitude, many instruments emerged to evaluate scientific attitudes. During these years, researchers have been used the various methods and instruments to measure attitudes toward science:

3.1 Qualitative Methods: even with the growth of qualitative methodology in educational research, only few studies are seen following the issue of student attitudes through group and clinical interviews (Osborne and Collins, 2000). While such studies are subject to restrictions of their generalizability, the richness of data does seem to give more insight into the origins of attitudes to school science than quantitative methods indicating that both methodologies have value. These methods have offers some pointers about the attitude of students towards scientific issues. In fact, in this way the relative popularity of subjects such as chemistry, physics and biology is measured among students. Studies by Howard (1995) and Osborne and Collins (2000) are some cases of these researches. In recent research, by means of group interviews, sixteen year old student attitudes and opinions towards science was deeply investigated. The results showed that chemistry are less attractive than physics to students (Osborne et al., 2003).

3.2 Quantitative Methods: Traditionally, researches on attitudes to science have been the more quantitative and have used positivistic methods (Krogh, 2005). More commonly, attitudes have been measured through the use of questionnaires that commonly consist of Likert-scale items where students are asked to respond to statements of the form:

- Science is fun.

- I would enjoy being a scientist. 
- Science makes me feel like I am lost in a jumble of numbers and words (Osborne et al., 2003).

One of the most common instruments is the Scientific Attitude Inventory (SAI) the developed by Moore in 1969 (Moore, 1969). Moore identified both positive and negative views of six separate domains of attitudes toward science that include:

i. The nature of the laws and/or theories of science-changeable versus unchangeable truths;

ii. The basis of scientific explanation-observation versus authority;

iii. Characteristics needed to operate in a scientific manner-independence of thought versus group thinking;

iv. The type of activity engendered in science-idea generating versus technology developing;

v. Progress in science-dependent on public understanding versus no need for public understanding;

vi. Science as a career - and satisfy visitors in interesting times tedious and uniform.

One of the most famous Scales is the questionnaire that developed by Moore and Sutman (1970). A feature of this scale is that all the attitude objects are concerned with aspects of science in society and not attitude to science as a school subject. The result has been the development of a plethora of scales that give differing degrees of emphasis to a broader range of attitude objects (Osborne et al., 2003). Another Questionnaire on attitudes developed by toward science Gogolin and Swartz (1992) and has assessed attitude of students towards mathematics. Another is the Views on Science-Technology-Society instrument developed by Aikenhead, Ryan, and Fleming (1989), although this placed more emphasis on determining students' views of the nature of science. However, their items were determined from views expressed by students and, for this reason; their instrument is often seen as offering greater validity than others. It has been adapted most recently by Bennett (2001) to determine undergraduates' views of chemistry and develop profiles of students who held positive and negative views of the subject (Osborne et al., 2003).

Concerns about scientific literacy and lack of leadership in science and technology, was the main issue in early 80's. Questionnaire of Simpson and Troost (1982), were developed in order to predict how students learn lifelong habits associated with the development of science. This questionnaire is to determine whether factors related to their homes, family, school and class, affects commitment and achievement of students in science? Simpson and Troost (1982) definition of commitment to science are including attitudes, interests, values and other effective behaviors.

Moore (1969) created a list (inventory) of candidate items (20-27 items per area) to evaluate students' agreement or disagreement with each. The initial inventory presented contained 127 items (Lichtenstein et al, 2008 Moore and Foy (1997) shortened the SAI from 60 to 40 questions, and changes were made to improve readability and eliminate gender-based language. In the original SAI, Moore had opted for a four-point Likert response scale with no midpoint. In the revision, they opted for the more common five-point response format, with the midpoint being "neutral/undecided." The underlying logical structure (six domains) and attitude direction (positive and negative) remained unchanged.

\section{Research Questions}

In this research the following questions were investigated:

i. The Persian scale of attitudes toward science has suitable validity?

ii. The Persian scale of attitude toward science is one-dimensional or multidimensional construct?

iii. Is there any significant different between attitudes of male and female secondary students toward science?

iv. Is there any significant different between attitudes of science and mathematics students toward science?

\section{Methodology}

Sample: The population of study is all second grade's sciences and mathematics students of secondary education in Isfahan city. Stratified random sampling was done to choose students. Finally a total of 300 boys and girls equally from the disciplines of sciences and mathematics participated in the study.

Instrument: instrument used in this study was the Persian translation of Simpson - Troost Attitude Questionnaire (STAQ). This Attitude questionnaire consists of 58 items on 5-point Likert-type scales. Six items of scales were reversed coding.

\section{Results}

\subsection{Reliability of Scale}

To measuring reliability of the scale and internal consistency Craonbach's alpha coefficient was used. Craonbach's 
alpha coefficient was calculated for 58 items set to be .84 . The Craonbach's alpha coefficient of each factor identified after factor analysis and set to be.44 to .89 (Table 1). These results indicate that questions of scale have appropriate internal consistency and demonstrate a construct.

\subsection{Construct Validity and Identifying Aspects of Scale}

To determine construct validity and identifying factors in items of scale, the exploratory factor analysis was used. Adequacy sample size tests for factor analysis was performed and the results showed that there are necessary conditions for factor analysis and can use this method (Table 2).

For factor analysis first was used the principal component analysis method. Results showed that five factors explaining a total of $35.8 \%$ of the variance for the entire set of variables and show the variance of students' attitudes towards science (Table 3).

Table 4 shows factors extracted after Varimax (orthogonal) rotation, as science is fun, classroom / teacher, self-directed efforts, anxiety toward science and family models, with each represented items and their factor loadings of each of them. In this table items with load factor less than .3 as items No. 30, 6 and 37 was removed from Persian scale and are given at the end of the table.

Five factors are explaining a total of $35.8 \%$ of the variance of scale and so have a fundamental role in explain the variance. Thus measuring attitudes toward science, is a multi-dimensional scale that its factors are explained the total variance.

\subsection{The Difference between Groups in Attitudes toward Science}

Table 5 shows mean and standard deviation of male and female students. Based on these results, female students had higher average than males.

Table 6 shows results of multivariate analysis of variance (MANOVA) test of difference between two groups of male and female students. Based on these results, there are not any significant differences between groups. In fact, gender has no effect on their attitudes.

Table 7 shows results of multivariate analysis of variance (MANOVA) test of differences between two groups of male and female students at each factor. Based on these results, there is significant difference between two groups of male and female in factor of Self-Motivated efforts at the level of at the level of $\mathrm{P}<0.02$.

Table 8 shows the mean and standard deviation of the students in science and mathematics Based on these results, science students have higher average than the mathematics students.

Table 9 shows results of MANOVA test of difference between two groups of science and mathematics students. Based on these results, there is no significant difference between two groups in attitude toward science at the level of $\mathrm{P}<0.00$.

Table 10 shows results of multivariate analysis of variance (MANOVA) test of differences between two groups of sciences and mathematics students at each factor. Based on these results, there is a significant difference between two groups in factor of science is fun at the level of $\mathrm{P}<0.00$. Also, there is a significant difference between two groups in factor of classroom / teacher at the level of $\mathrm{P}<0.03$.

\section{Conclusions}

The results of this study showed that the Persian form of attitude toward science scale has good validity and reliability (coefficient alpha .84) among secondary school students in Isfahan. The findings are congruent with of Simpson and Oliver (1990), Atawater et al. (1995), Greenfield (1997) and spellman and Oliver (2001) which respectively have calculated this coefficient alpha to be $.88, .88, .92$ and .87 . Cronbach's alpha reliability domain of factors identified after factor analysis .44 to .89 that means that the scale have appropriate internal correlation and explains a construct.

The results show that the scale is a multidimensional one. Five extracted factors identified in the exploratory factor analysis explaining a total of $35.8 \%$ of the variance for the entire set of variables and so five factors have a fundamental role in explain the variance. Thus, this multi-dimensional scale with its five factors namely science is fun, class / teacher, self -directed efforts, anxiety toward science and family model can measure secondary students attitudes towards so this Persian scale can be used in similar studies in this area. Owen et al. (2008) in exploratory factor analysis on this scale among secondary school students identified ten factors that in the confirmatory factor analysis, these factors decreased to the five factors namely science is fun for me, self-directed efforts, motivating science class, family models and peer models. Thus, the factors identified in this study in four cases are congruent with the results that Owen and colleagues (2008) and peer model has replaced with anxiety toward science among 
Iranian secondary students. In Osborne et al. (2000) report anxiety toward science has mentioned as a effective components of attitude toward science. These findings indicate that among the Iranian secondary students, peers and friends attitudes views can not be a effective factor on attitudes to science, while the parents attitudes to science is impressive in this field. Also Iranian secondary students' anxiety toward science and scientific issues is an effective factor in their view toward science.

Results show that the first factor, science is fun with $16.76 \%$ has highest explaining the variance. So the factor that makes students' attitudes students more positive toward science and attracts them to science is science is fun. The factors classroom / teacher and self-directed efforts respectively with $5.45 \%$ and $5.33 \%$ of variance play an equal role in the attitude of students toward science. This issue shows that the educational environment and school and classroom factors such as teacher, director and science curriculum can also be effective in student attitude towards science. The factors of anxiety toward science and family model respectively explain $3.59 \%$ and $3.65 \%$ of the variance, so play the lowest role among the factors in the scale of attitudes toward science. However, these findings indicate that students' anxiety toward science and family members' views toward science are effective in determining the secondary students' attitude towards science, but their affects are less than the effects of science is fun, classroom / teacher and self-directed efforts. Results show that there is not a significant difference between male and female students in attitudes toward science that mean according to the findings on the gender is not ineffective to determining their attitudes to science. Although this findings not congruent with result of Osberne and Collins (2000) but are in congruent with results of Greenfield (1997) and Osborne et al. (2003). However, the third factor, namely the self-directed efforts, there was a significant difference between males and females and the average of female students were higher than male students. This means that female students have more self-directed efforts to succeed in science and improve their attitude towards science than their male peers. However, based on the results of this study, there is a significant different between science and mathematics students in attitudes toward science. Science students have more positive attitudes toward science than mathematics students. Furthermore in the first factors (science is fun) and second factor (classroom / teacher), the science students have higher average than the mathematics students.

In general, the results of this study are concluded that considering the importance an attractiveness of science in determining attitudes of students to science, science curricula planners in secondary education should pay more attention to this issue in future programs also it is important that educational authorities consider to key roles of teachers and environmental issued and science educators in science classes. We should consider that reducing anxiety toward science lead to improving positive attitude toward science so is recommended that science teachers have more attention to these issues. Families can also play an important role in attitude toward science so the parents' awareness of scientific issues can be important in this regard. The interesting finding is the less important role of peers and friends in attitudes toward science among the Iranian students so must identify the reasons of this issue and should be presented strategies for its improvement. It is recommended to researchers that use this validated scale in the other student groups and with regard to other components such as social class, academic performance, parents educational level, etc.

\section{Acknowledgement}

Authors are heartily thankful to Dr. Simpson for his guidance and also Dr. Oliver who giving us the STAQ and all students that have participated in this study.

\section{References}

Aikenhead, G., Ryan, A. G., \& Fleming, R. W. (1989). Views on Science-Technology-Society, Saskatoon, Saskatchewan: Department of Curriculum Studies.

Atawater, M. M., Wiggins, J., \& Gardner, C. M. (1995). A study of urban middle school students with high and low attitudes toward science. Journal of Research in Science Teaching, 32, 665-667. http://dx.doi.org/10.1002/tea.3660320610

Bak, H. J. (2001). Education and public attitudes toward science: Implications for the "Deficit Model" of education and support for science and technology, Social Science Quarterly, 82(4), 779-795. http://dx.doi.org/10.1111/0038-4941.00059

Beaton, A., Martin, M. O., Mullis, I., Gonzalez, E. J., Smith, T. A., \& Kelley, D. L. (1996). Science Achievement in the Middle School Years: IEA's Third International Mathematics and Science Study, Chestnut Hill, MA: Boston College.

Bennett, J. (2001). The development and use of an instrument to assess students' attitude to the study of chemistry, International Journal of Science Education, 26, 141-169 
Breakwell, G. M., \& Beardsell, S. (1992). Gender, parental and peer influences upon science attitudes and activities, Public Understanding of Science, 1, 183-197. http://dx.doi.org/10.1088/0963-6625/1/2/003

Fishbein, M., \& Ajzen, J. (1975). Beliefs, attitude, intention and behavior: An introduction to theory and research, Reading, MA: Addison-Wesley.

George, R. (2006). A cross-domain analysis of change in students' attitudes toward science and attitudes about the utility of science, International Journal of Science Education, 28(6), 571-589

Gogolin, L., \& Swartz, F. (1992). A quantitative and qualitative inquiry into the attitudes toward science of nonscience college majors, Journal of Research in Science Teaching, 29, 487-504. http://dx.doi.org/10.1002/tea.3660290505

Greenfield, T. A. (1997). Gender- and grade-level differences in science interest and participation, Science Education, 81, 259-276. http://dx.doi.org/10.1002/(SICI)1098-237X(199706)81:3<259::AID-SCE1>3.0.CO;2-C

Havard, N. (1996). Student attitudes to studying A-level sciences, Public Understanding of Science, 5(4), 321-330. http://dx.doi.org/ 10.1088/0963-6625/5/4/002

Hurd, P. H. (1982). Sate of precollege education in mathematics and science, National Academy of Science and National Academy of Engineering, Washington, DC.

Kremer, B. K., \& Walberg, H. J. (1981). A synthesis of social and psychological influences on science learning, Science Education, 65, 11-23. http://dx.doi.org/10.1002/sce.3730650104

Krogh, L. B. (2005). Studying students' attitudes towards science from a cultural perspective but with a quantitative methodology: Border crossing into the physics classroom, International Journal of Science Education, 27(3), 281-302

Lichtenstein, M. J., Owen, S. V., Blalock, C. L., Liu, Y., Ramirez, K. A., Pruski, L. A., Marshall, C. E., \& Toepperwein, M. A. (2008). Psychometric reevaluation of the scientific attitude inventory-revised (SAI-II), Journal of Research in Science Teaching, 45(5), 600-616. http://dx.doi.org/10.1002/tea.20244

Moore, R. W., \& Sutman, F. X. (1970). The development, field test and validation of an inventory of scientific attitudes, Journal of Research in Science Teaching, 7, 85-94. http://dx.doi.org/10.1002/tea.3660070203

Moore, R. W. (1969). The Development, Field test, and Validation of the Scientific Attitude Inventory, Unpublished dissertation, Temple University.

Moore, R. W., \& Foy, R. L. H. (1997). The scientific attitude inventory: A revision (SAI-II). Journal of Research in

http://dx.doi.org/10.1002/(SICI)1098-2736(199704)34:4<327::AID-EA3>3.0.CO;2-T.

Myers, R. E., \& Fouts, J. T. (1992). A cluster analysis of high school science classroom environments and attitude toward science, Journal of Research in Science Teaching, 29, 929-937. http://dx.doi.org/10.1002/tea.3660290904

Osborne, J. F., \& Collins, S. (2000). Pupils' and Parents'Views of the School Science Curriculum, London: King's College London.

Osborne, J., Simon, S., \& Collins, S. (2003). Attitudes towards science: a review of the literature and its implications, International Journal of Science Education, 25(9), 1049-1079. http://dx.doi.org/10.1080/0950069032000032199

Owen, S. V., Froman, R. D., \& Moscow, H. (1981). Educational psychology (2 ${ }^{\text {nd }}$ Ed.), Boston: Little, Brown \& Co.

Owen, S. V., Toepperwein, M., Lichtenstein, M. J., Blalock, C. L., Liu, Y., Pruski, L. A., \& Grimes, K. (2008). Finding pearls: Psychometric reevaluation of the Simpson-Troost attitude questionnaire, Science Education, 92(6), 1076-1095. http://dx.doi.org/10.1002/sce.20296

Simpson, R. D., \& Oliver, J. S. (1990). A summary of major influences on attitudes toward and achievement in science among adolescent students, Science Education, 74, 1-18. http://dx.doi.org/10.1002/sce.3730740102

Simpson, R. D., \& Troost, K. M. (1982). Influences on commitment to and learning of science among adolescent students, Science Education, 66(5), 763-781. http://dx.doi.org/10.1002/sce.3730660511

Spellman, J. E., \& Oliver, J. S. (2001). The relationship between attitude toward science with enrollment in a $4 * 4$ block schedule. Proceedings of Annual Meeting of the Association for the Education of Teacher in Science (pp. 3-30), Costa Mesa, CA. 3-30

Talton, E. L., \& Simpson, R. D. (1986). Relationships of attitude toward self, family and school with attitude toward science among adolescents, Science Education, 70(4), 365-374. http://dx.doi.org/10.1002/sce.3730700403 
Taltont, E. L., \& Simpson, R. D. (1985). Relationships between peer and individual attitudes toward science among adolescent students, Science Education, 69, 19-24. http://dx.doi.org/10.1002/sce.3730690103

Turkmen, L. (2007). The influence of elementary science teaching method courses on Turkish teachers college elementary education major students' attitudes towards science and science teaching, Journal of Baltic Science Education, 6(1), 66-77

Table 1. Reliability of each scale factors after factor analysis

\begin{tabular}{cc}
\hline Factors & Cranach's alpha \\
\hline Total Scale & .84 \\
$1^{\text {st }}$ Factor & .89 \\
$2^{\text {nd }}$ Factor & .62 \\
$3^{\text {rd }}$ Factor & .68 \\
$4^{\text {th }}$ Factor & .44 \\
$5^{\text {th }}$ Factor & .67 \\
\hline
\end{tabular}

Table 2. Results of Adequacy sample size tests for factor analysis

\begin{tabular}{ll}
\hline KMO and Bartlett's Test & .79 \\
\hline Bartlett's Test and Approx. chi-square & 6464.341 \\
df & 1653 \\
Sig. & 0.00 \\
\hline
\end{tabular}

Table 3. Extracted scale factors and number of items that reveal any factor

\begin{tabular}{ccccc}
\hline Factors & Items with upper than 0.3 load factor & $\%$ of Variance & Cumulative $\%$ & Total \\
\hline $1^{\text {st }}$ & $\begin{array}{l}55,32,57,15,8,50,3,26,25,29,21,11,51, \\
22,46,1,43,7,2,52,10\end{array}$ & 16.76 & 16.76 & 9.72 \\
$2^{\text {nd }}$ & $47,31,28,18,16,20,17,5,4,19$ & 22.21 & 5.45 & 3.16 \\
$3^{\text {rd }}$ & $34,58,41,9,36,45,38,13,40,12$ & & & 3.09 \\
$4^{\text {th }}$ & $53,35,54,49,33,14,23,39$ & 27.55 & 5.33 & \\
$5^{\text {th }}$ & $42,48,44,27,56,24$ & 32.14 & 4.59 & 2.66 \\
& & 35.80 & 3.65 & 2.12 \\
\hline
\end{tabular}


Table 4. Factors extracted after Varimax rotation with items revealed and each of their factor loadings.

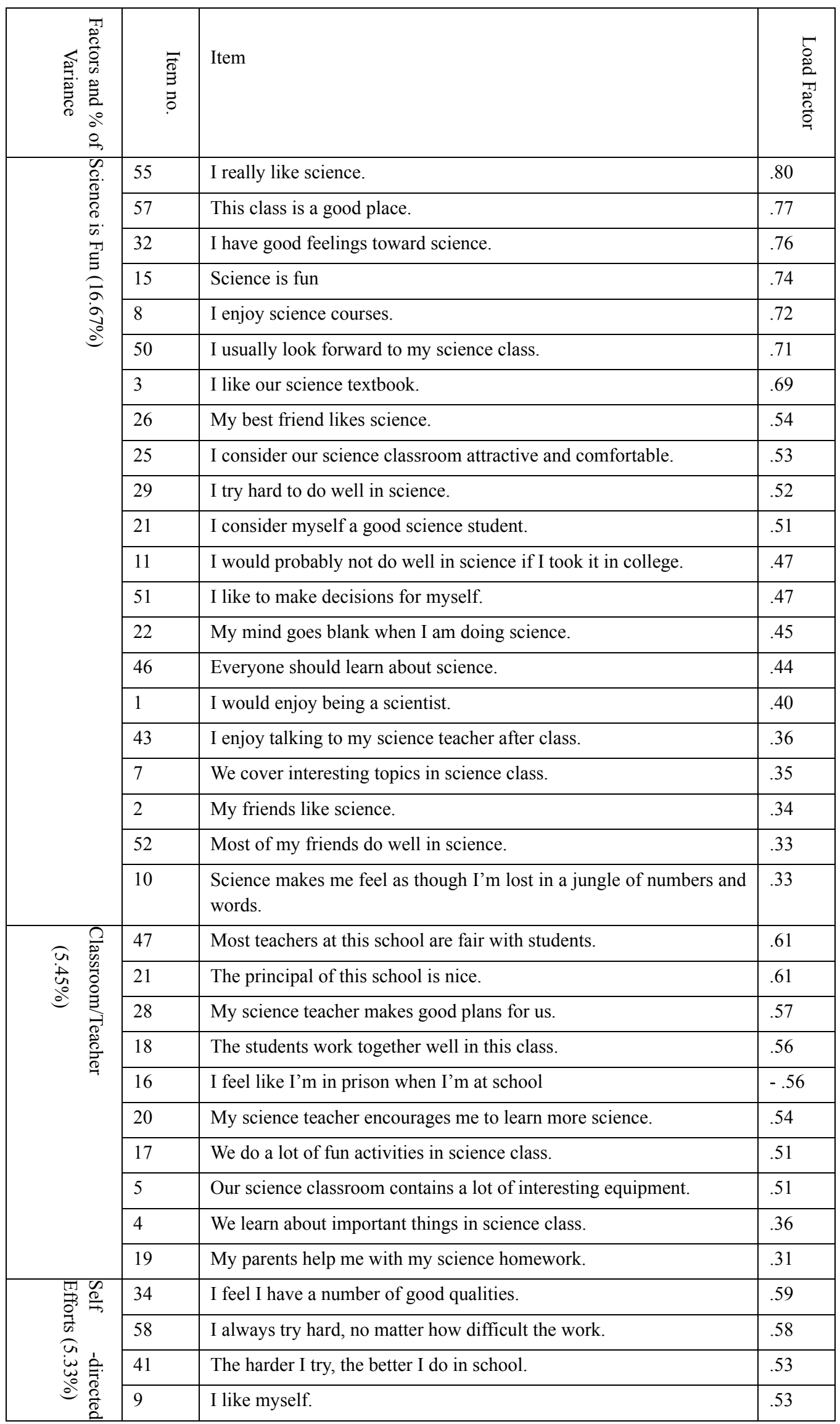




\begin{tabular}{|c|c|c|c|}
\hline & 36 & My parents expect me to do well in school. & .48 \\
\hline & 45 & I think I am capable of becoming, an engineer, scientist or doctor. & .43 \\
\hline & 38 & I don't have many friends in this class. & .42 \\
\hline & 13 & I always try to do my best in school. & .41 \\
\hline & 40 & My science teacher expects me to make good grades. & .39 \\
\hline & 12 & I like to make decisions for myself. & .38 \\
\hline & 53 & Sometimes my science teacher makes me feel dumb. & .66 \\
\hline$\stackrel{\vec{Q}}{<}$ & 35 & I feel nervous in science class. & .65 \\
\hline ڤે & 54 & I am under great pressure at school. & .58 \\
\hline$\vec{a}$ & 49 & Science tests make me nervous. & .57 \\
\hline$\stackrel{0}{9}$ & 33 & At times I think I am no good at all. & -.35 \\
\hline$\stackrel{0}{I}$ & 14 & I don't have many friends at this school. & .33 \\
\hline : & 23 & I feel like I have little control over what happens to me at school. & .33 \\
\hline & 39 & Luck seems to be more important in life than hard work. & .33 \\
\hline ஸि & 48 & My father likes science. & .57 \\
\hline$e^{0} \ddot{<}$ & 42 & My family watches science programs on TV. & .56 \\
\hline$\stackrel{0}{\circ}$ & 27 & I argue a lot with my family. & .52 \\
\hline & 44 & My mother likes science. & .49 \\
\hline & 24 & I am a member of a happy family. & .45 \\
\hline & 56 & My brothers and sisters like science. & .41 \\
\hline$\overline{\bar{O}} \overline{\overline{0}} \overline{\overline{0}}$ & 30 & When I fail that makes me try that much harder. & \\
\hline $\overrightarrow{2}$ & 6 & The students in this class aren't much fun. & \\
\hline 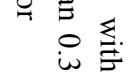 & 37 & I think scientists are neat people. & \\
\hline
\end{tabular}

Table 5. Mean and standard deviation of males and females in attitudes toward science test

\begin{tabular}{lcccc}
\hline \multirow{2}{*}{\multicolumn{1}{c}{ Factors }} & \multicolumn{4}{c}{ Group } \\
\cline { 2 - 5 } & \multicolumn{2}{c}{ male } & \multicolumn{2}{c}{ female } \\
\cline { 2 - 5 } & SD & Mean & SD & Mean \\
\hline Science is Fun & 13.97 & 55.21 & 12.74 & 58.14 \\
Classroom/Teacher & 5.71 & 18.96 & 5.99 & 19.51 \\
Self - directed Efforts & 4.83 & 32.46 & 4.44 & 33.68 \\
Anxiety toward Science & 4.83 & 16.16 & 4.40 & 16.72 \\
Family Model & 4.41 & 14.82 & 3.97 & 15.47 \\
\hline
\end{tabular}

Table 6. Results of MANOVA test of differences in male and female students' attitudes toward science.

\begin{tabular}{ccccc}
\hline wilks'Lambda & F & Sig. & Eta $^{2}$ & O. Power \\
\hline 0.96 & 1.98 & 0.08 & 0.03 & 0.66 \\
\hline
\end{tabular}


Table 7. Results of MANOVA differences in male and female students in each of the factors of attitude toward science test.

\begin{tabular}{lccccccc}
\hline Factors & R square & df & Mean square & F & Sig. & Eta $^{2}$ & O. Power \\
\hline Science is Fun & 640.66 & 1 & 640.66 & 3.51 & 0.06 & 0.01 & 0.47 \\
Classroom/Teacher & 22.62 & 1 & 22.62 & 0.65 & 0.41 & 0.00 & 0.12 \\
Self -directed Efforts & 112.09 & 1 & 112.09 & 5.19 & 0.02 & 0.01 & 0.62 \\
Anxiety toward Science & 23.28 & 1 & 23.28 & 1.08 & 0.29 & 0.00 & 0.18 \\
Family Model & 31.56 & 1 & 31.56 & 1.78 & 0.18 & 0.00 & 0.26 \\
\hline
\end{tabular}

Table 8. Mean and standard deviation of science and mathematics students in term of factors.

\begin{tabular}{lcccc}
\hline \multirow{2}{*}{ Factors } & \multicolumn{4}{c}{ Group } \\
\cline { 2 - 5 } & \multicolumn{2}{c}{ Mathematics } & \multicolumn{2}{c}{ Science } \\
\cline { 2 - 5 } & Mean & SD & Mean & SD \\
\hline Science is Fun & 53.08 & 14.35 & 58.14 & 12.74 \\
Classroom/Teacher & 18.51 & 5.64 & 19.51 & 5.99 \\
Self -directed Efforts & 32.90 & 4.47 & 33.68 & 4.44 \\
Anxiety toward Science & 16.84 & 4.46 & 16.72 & 4.40 \\
Family Model & 15.27 & 4.13 & 15.47 & 3.97 \\
\hline
\end{tabular}

Table 9. Results of MANOVA test in science and mathematics students in attitude toward science.

\begin{tabular}{ccccc}
\hline wilks'Lambda & F & Sig. & Eta $^{2}$ & O. Power \\
\hline .0 .89 & 6.57 & 0.00 & 0.10 & 0.99 \\
\hline
\end{tabular}

Table 10. Results of MANOVA differences in science and mathematics students in each of the factors of attitude toward science test.

\begin{tabular}{lccccccc}
\hline \multicolumn{1}{c}{ Factors } & R square & df & Mean square & F & Sig. & Eta $^{2}$ & O. Power \\
\hline Science is Fun & 3923.22 & 1 & 3923.22 & 23.36 & 0.00 & 0.07 & 0.99 \\
Classroom/Teacher & 160.02 & 1 & 160.02 & 4.72 & 0.03 & 0.01 & 0.58 \\
Self -directed Efforts & 8.77 & 1 & 8.77 & 0.40 & 0.52 & 0.00 & 0.09 \\
Anxiety toward Science & 47.89 & 1 & 47.89 & 2.24 & 0.13 & 0.00 & 0.32 \\
Family Model & 4.97 & 1 & 4.97 & 0.28 & 0.59 & 0.00 & 0.08 \\
\hline
\end{tabular}

